\title{
Exploring the use and influence of human resource policies within South African municipalities
}

\begin{tabular}{|c|c|}
\hline \multicolumn{2}{|c|}{$\begin{array}{l}\text { Authors: } \\
\text { Lonwabo Makapela }^{1} \text { (1) } \\
\text { Nontsikelelo D.P. } \\
\text { Mtshelwane }^{1} \text { (D) }\end{array}$} \\
\hline \multicolumn{2}{|c|}{$\begin{array}{l}\text { Affiliations: } \\
{ }^{1} \text { School of Industrial } \\
\text { Psychology and Human } \\
\text { Resource Management, } \\
\text { Faculty of Economic } \\
\text { Management Sciences, } \\
\text { North-West University, } \\
\text { Potchefstroom, South Africa }\end{array}$} \\
\hline \multicolumn{2}{|c|}{$\begin{array}{l}\text { Corresponding author: } \\
\text { Nontsikelelo Mtshelwane, } \\
\text { Debbie.mtshelwane@nwu. } \\
\text { ac.za }\end{array}$} \\
\hline \multicolumn{2}{|c|}{$\begin{array}{l}\text { Dates: } \\
\text { Received: } 01 \text { Dec. } 2020 \\
\text { Accepted: } 08 \text { Mar. } 2021 \\
\text { Published: } 30 \text { Apr. } 2021\end{array}$} \\
\hline \multicolumn{2}{|c|}{$\begin{array}{l}\text { How to cite this article: } \\
\text { Makapela, L., \& Mtshelwane, } \\
\text { N.D.P. (2021). Exploring the } \\
\text { use and influence of } \\
\text { human resource policies } \\
\text { within South African } \\
\text { municipalities. SA Journal } \\
\text { of Human Resource } \\
\text { Management/SA Tydskrif vir } \\
\text { Menslikehulpbronbestuur, } \\
\text { 19(0), a1534. https://doi. } \\
\text { org/10.4102/sajhrm. } \\
\text { v19i0.1534 }\end{array}$} \\
\hline \multicolumn{2}{|c|}{$\begin{array}{l}\text { Copyright: } \\
\text { (C) 2021. The Authors. } \\
\text { Licensee: AOSIS. This } \\
\text { is licensed under the } \\
\text { Creative Commons } \\
\text { Attribution License. }\end{array}$} \\
\hline \multicolumn{2}{|l|}{ Read online: } \\
\hline 口ist: & $\begin{array}{l}\text { Scan this QR } \\
\text { code with your } \\
\text { smart phone or } \\
\text { mobile device } \\
\text { to read online. }\end{array}$ \\
\hline
\end{tabular}

Orientation: There is a gap between the administrative expertise held by the human resource (HR) function and the delivery of services.

Research purpose: The purpose of this article was to explore the perceptions of both the HR managers and employees, on how HR policies are communicated and experienced, respectively, within South African municipalities.

Motivation for the study: To help policy users within the South African municipalities gain deeper awareness and understanding of the influence their use of HR policies has on employees' morale and performance within the workplace.

Research approach/design and method: This qualitative study utilised an interpretivist paradigm and a qualitative descriptive strategy. A convenience, quota, purposive and inclusion criteria sample comprising three HR managers $(n=3)$ and 12 employees $(n=12)$ was used. Semi-structured, face-to-face interviews were conducted and analysed by employing thematic analysis.

Main findings: The findings of the study indicated that HR managers experience a lack of clear guidance from draft recruitment-and-selection policy and draft learning-anddevelopment policy, and employees experience challenges with regards to the lack of communication on performance management.

Practical/managerial implications: This study promotes fairness and equality during the use of the three mentioned HR policies in order to provide all employees with the necessary developmental opportunities within municipalities.

Contribution/value-add: This study contributes to the body of knowledge concerning the establishment of a municipal culture that values human capital, prioritises the growth and well-being of employees and understands the valuable link between human resource management and service delivery.

Keywords: human resource policies; South African municipalities; recruitment and selection; learning and development; performance management; AMO theory.

\section{Introduction}

Municipalities are a sphere of the government body situated closest to the people (Schwella, Botha, Brand, Engelbrecht, \& Eijbergen, 2015). Swift transformations within South African municipalities over the past 25 years have placed strong emphasis on employees within these organisations to be capacitated with the necessary skills and competencies that help them meet the vast demands of South African citizens (Cloete, Eigelaar-Meets, Fortuin, \& Sewell, 2016). However, in order for this intention to realise, human resources (HR) within municipalities have to be managed efficiently (Cloete et al., 2016). Human resources are a complex and important resource within organisations. Therefore, HR should be managed in close relationship with the organisation's strategy to gain a clear and structured competitive advantage (Rees \& Smith, 2017). Effective human resource management (HRM) and development can help improve the municipality's organisational performance, thereby ensuring quality service delivery to its communities (Cloete et al., 2016).

Human resource policies coordinate knowledge in the interplay of the employee, job and the organisation (Legge, 1995). In a well-managed organisation, the performance management system holds managers accountable for applying the principles of the organisation (Meyer, 2016). Tinti, Venelli-Costa, Vieira and Cappelloza (2017) argued that HR policies are necessary to manage people at work, specifically in functions such as hiring, training, evaluation, remuneration and the provision of a sound and secure environment for company employees. Investments in HR 
policies such as recruitment and selection, training and development (TD) and performance management have clear gains. Such policies boost the pro-environmental behaviour within the organisation, thereby benefiting the reputation and financial performance of the firm (Pham, Tuckova, \& Jabbour, 2018).

However, there are administrative dysfunctions and deficiencies within the municipalities, which have resulted in protest marches and damage to property within communities (Thornhill \& Cloete, 2014). Consequently, municipalities, as nodal points of service delivery, find it challenging to manage the growing demands by communities for improved services. Public servants are tasked to make and implement public policy, which would deliver sufficient services to the public; however, current management research appears far removed from the world of practice, being overly theoretical and abstract (Cloete et al., 2016). Therefore, the present study aims to gain an understanding of HR policy implementation through the views of both managers and employees, in hopes of promoting commitment, accountability and effective use of HR policies within South African municipalities.

\section{Research purpose and objectives}

The purpose of this article was to explore the use and influence of HR policies within municipalities. The objectives of the study were to (1) ascertain how HR policies (recruitment and selection, learning and development [L\&D], and performance management) are communicated to employees by the HR department within the municipalities, (2) determine the challenges experienced during the implementation of these HR policies, (3) determine how employees are informed about these implemented HR policies, (4) ascertain the experience of employees on the ways these HR policies are implemented within municipalities and (5) determine what challenges employees experience as a result of management's implementation of these HR policies.

\section{Literature review}

\section{South African local government}

South Africa is regarded as a developmental and democratic state that builds its legitimacy on its capacity to encourage concurrent production and economic activities as well as economic growth. The aim is to reduce poverty and improve the living conditions of its people (National Capacity-building Framework, 2008). In order to achieve this, local government is given the critical role by the Constitution to develop South African citizens' living conditions through quality service delivery (Constitution of the Republic of South Africa, 1996). However, despite immense responsibility placed on South African local government, in many respects, municipalities are failing to fulfil this responsibility (Siddle \& Koelble, 2012).

The performance of numerous municipalities across the country has demonstrated huge deficiencies in fulfilling both their constitutional and legislative obligations (Koma,
2010). Khambule (2018) concurred by stating that weakening institutional ability and arrangements within municipalities take place through political interference, lack of efficient bureaucracy and gross corruption. The consequences of inefficient service delivery are profound. Therefore, it is important that the causes of such deficiency should be understood (Siddle \& Koelble, 2012). A prominent issue faced by local government is the lack of capacity. The main issue that is a concern for municipalities is appointing unqualified staff, particularly at a senior level. The associated problems are cadre deployment, staff retention and incompetent staff. Local government is unable to meet citizens' demands because of inherent incapacities to plan for development with major inabilities attributed to the lack of capacity within municipalities. Moreover, insufficiencies in the skills of practitioners, lack of understanding of local economies and a lack of integration between local authorities, communities and the business community further perpetuate the administrative dysfunctions within municipalities (Mashamaite \& Lethoko, 2018).

\section{Strategic human resource management}

Human resource management is described as the management of work and people to attain desired outcomes. As a consequence of their drive to act more strategically, organisations have focused on strategic HRM (Rees \& Smith, 2017). Although the definition for strategic HRM is more complex, HR strategies aim to align the organisation's objectives, HR policies and programmes with strategic business unit plans (Rees \& Smith, 2017).

According to Greer (1995), strategic HRM can be perceived as the endeavour to link HR policies and practices to an explicit strategy, which subsequently connects to the organisational strategy. Strategic HRM, consequently, entails long-term, top-level management decisions and actions about the organisation's HR architecture. The latter is constructed and executed in a way that is integrated fully with the organisation's overall general strategic management (Swanepoel, Erusmus, Van Wyk, \& Schenk, 2003). It can therefore be surmised that strategic HR is an approach that centres on longer-term resourcing of organisational goals as well as progressive essence of work, whilst integrating other HR strategies into the overall business strategy (CIPD, 2019a).

\section{Human resource policies}

According to the Makhuduthamaga Municipality (2008), municipalities have over $30 \mathrm{HR}$ policies, which are grouped in terms of several HR functions. These policies regulate aspects such as employment equity, leave, recruitment, selection and retention as well as employment benefits and conditions. The policies also focus on issues such as education, training and development (ETD), health and welfare as well as labour relations. However, the CIPD (2019b) encourages organisations to focus more on an adapted policy mixture, in order to create 
sustainable and successful relationships between employees and the particular organisation, instead of what has worked for other organisations. The present study focused particularly on three HR policies, namely recruitment and selection, L\&D and performance management.

\section{Recruitment and selection}

Recruitment and selection can be defined as the process of encouraging people to apply for jobs in an organisation in order to establish a pool of suitably qualified and experienced applicants from whom one or more employees can be selected (Hunter, 2012). Demo, Neiva, Nunes and Rozzett (2012) view such policies as organisational propositions to seek out employees, stimulate them to apply and select them and then harmonise the person's competencies with the characteristics and demands of the organisation. A number of factors affect the manner in which the recruitment and selection policy is applied within and outside the organisation. The actual content and statement of intent of such a policy dictate the recruitment efforts within the organisation ( $\mathrm{Nel}$ et al., 2011). Legislation affects the implementation of these policies. For example, the South African Labour Acts prohibit discriminating against applicants on the basis of factors such as race, religion or age. Therefore, organisations should consider these regulations closely when drawing up job advertisements (Hunter, 2012). A company with a favourable reputation for practising fairness and equality, and providing a supportive working environment, attracts a higher quality pool of employees (Kleynhans, Markham, Meyer, Van Aswegen, \& Pilbeam, 2009).

\section{Learning and development}

Learning and development is an organisational strategy that communicates the organisation's mandatory workforce capabilities, skills or competencies, and how these components can be developed to ensure a sustainable and successful organisation (Hunter, 2012). The term ETD (or TD) is used to describe the practices that directly and indirectly promote and support learning, whilst human resource development (HRD) refers to the various processes, systems, methods, procedures and programmes an organisation employs to develop its human resources, thereby equipping its employees and helping them contribute to the organisation's performance (Meyer, 2016). The link between these concepts is that ETD provides shortand medium-term interventions to ensure that the longterm goals of HRD are achieved (Meyer, 2016). Several governments prefer the term ETD for their HRD practices. However, consistent with international trends, the South African private sector has embraced the term L\&D to denote the work of their training department. Skills development through education and training interventions is a robust lever that increases both individuals' opportunity and the institution's prosperity (Nel et al., 2011).

The objective of HRD is to strengthen South Africa's HR base to deliver skilled and capable employees who can support
South Africa's socioeconomic development and growth (DHET, 2010). Despite the previously mentioned benefits, organisational actors (line managers, HR department and employees) continue to work in silos instead of collaborating, thereby preventing municipalities from meeting their defined development objectives (Cloete et al., 2016). This results in low employee empowerment and inadequate incentive structures. To rectify these deficiencies seems to be a significant point within the HRD agenda for policy implementation (Umashev \& Willett, 2008).

\section{Performance management}

Performance management has a strong component focusing on training and developing employees. General performance management allows managers to focus on the key tasks and goals. Such management provides a systematic basis for identifying and solving related problems and encourages the development of people in the organisation (Hunter, 2012). Performance management policies aim to implement strategy within the organisation. Such a strategy is a vehicle for cultural change and provides input to other HR systems such as development and remuneration (Nel et al., 2011). Literature on HR policy and development highlights the need for an integrated approach to manage performance as a critical factor in the successful improvement of any service delivery (Harris, 2005). It is crucial to establish integrative and well-understood performance processes that encourage a 'whole-system' approach. Such an approach identifies organisational priorities, and provides clarity about required actions and the meaning for individuals at different levels of the organisation (White, 2000). Therefore, it is important to understand how performance management policies are used within organisations (Bhuyan, Jorgensen, \& Sharma, 2010; Mthethwa, 2012).

\section{The use of human resource policies}

Policy implementation refers to the mechanisms, resources and relationships that link policies to programme action (Mthethwa, 2012). Implementation, more specifically, means the carrying out, accomplishing, fulfilling, producing and completing of a given task (Mthethwa, 2012). It is often assumed that once a policy has been formulated, it will be implemented readily. Such an assumption may be valid for First World nations, but not for policies formulated in many Third World nations. In the latter countries, governments tend to formulate broad, sweeping policies where governmental bureaucracies often lack the capacity for implementation (Smith, 1973). Implementing agents often fail to notice that the policies are inconsistent with their own organisation's interests and agendas (Firestone, 1989). Studies demonstrate similar trends in which misunderstanding about implementation can be attributed to lack of effort, incomplete buy-in or employees' explicit rejection of the reform ideas (Spillane, Reiser, \& Reimer, 2002). This means that planned learning structures are critical, allowing stakeholders to interpret the policy and its 
implications for the organisation's specific behaviours (Spillane et al., 2002). Consequently, it is important to understand the nature of policy implementation. Such resources can help ensure that employees are capacitated by policies that guide exhaustive recruitment and selection, as well as training activities, and provide employees the opportunity to participate within the organisation (BeltranMartin \& Bou-Llusar, 2018). Human resource policies shape individual and aggregate characteristics of employees. These policies enhance employees' 'ability to perform', 'motivation to perform' and 'opportunity to perform' (Purcell, Kinnie, Hutchinson, Rayton, \& Swart, 2003). The ability-motivationand-opportunity (AMO) framework is discussed in the following section.

\section{Ability, motivation and opportunity as theoretical framework}

The model describing abilities (A), motivation (M) and opportunities $(\mathrm{O})$ provides a comprehensive theoretical framework that integrates complex relationships (Cummings $\&$ Schwab, 1973). The AMO theory influences performance in employees' ability, motivation and opportunity to participate within the organisation (Appelbaum, Bailey, Berg, \& Kallegerg, 2000). The theory emphasises the importance of considering the competencies of individuals, their motivation as well as their opportunity to participate and apply their skills, knowledge and ideas in the workplace through various defined roles (Cloete et al., 2016). It advocates that the management system within any organisation should be designed to meet employees' needs for developing skills and motivation.

Katou and Budhwar (2010) found that ability is linked to skills, motivation to attitudes and opportunity to behaviour. The AMO theory offers a base from which to build a functional HRM system within an organisation (Hall, Pilbeam, \& Corbridge, 2013; Paauwe, 2009). As mentioned in the methods section, the objective of the present study was to explore the extent to which the use of HR policies influences employees' abilities, motivation and opportunities to participate and contribute to their performance at work. The further objective was to operationalise the AMO theory in order to explain how effective line managers implement $\mathrm{HR}$ policies within their organisations (Bos-Nehles, Van Riemsdijk, \& Looise, 2013). Cheema and Javed (2017) supported the use of the AMO model, noting that it could be used in helping decide the concerns of management in Green HRM. The AMO theory is common in conceptualising how HR management practices influence performance (Rayner \& Morgan, 2018). Sterling and Boxall (2013) used the AMO framework to analyse variations in what knowledge workers acquired and how they acquired it, within the context of workplace learning. In their study, McCarthy and Milner (2020) found that the AMO framework could be used in examining managers' coaching ability, their motivation to coach and whether or not they had the opportunity to coach.

\section{Research design Research approach}

The research study followed an interpretivist paradigm and qualitative approach. Interpretivism helps explore everyday practical concerns to determine how people develop and construct their own interpretations based on their experience of certain phenomena (Cammarata, 2012; Liamputtong, 2013; Silverman, 1994; Van Manen, 1990). The mentioned method moves beyond merely describing data. Instead, the aim is to interpret the findings without deviating too widely from the literal description as such (Bradshaw, Atkinson, \& Doody, 2017).

The qualitative approach is used to describe, understand and capture the essence of a specific complex phenomenon from the participants' viewpoint (Edmonds \& Kennedy, 2013; Leedy \& Ormrod, 2014; Merriam, 2009). The reason is that the researcher sought an in-depth understanding about the use of HR policies from the managers' perspectives and the influence of these policies as experienced by the employees of South African municipalities (Burns \& Grove, 2009; Malagon-Maldonado, 2014). Through this, the researcher sought an in-depth understanding of individuals' experiences. The focus was on the literal descriptions and understanding of the use and influence of HR policies as phenomenon.

\section{Research strategy}

The research strategy utilised in this study is a qualitative descriptive strategy. The use of a qualitative descriptive strategy is particularly relevant where information is required directly from those experiencing the phenomenon under investigation, where time and resources are limited (Neergaard, Oleson, Anderson, \& Sondergaard, 2009). Through this approach, the researcher sought an in-depth understanding of individuals' experiences. The focus was on the literal descriptions and understanding of the use and influence of HR policies as phenomenon. This understanding was reached by analysing and interpreting meaning of events as ascribed to by the participants (Bradshaw et al., 2017).

\section{Research method}

\section{Research setting}

Permission was granted by three South African municpalities situated in North West, Guateng and Eastern Cape provinces. The study was conducted amongst emplpoyees from the abovementioned provinces to provide an overview of the use of HR policies from multiple provinces instead of only one. The provinces were chosen through convenience sampling, providing the researcher easy access to municipal offices. Interviews were conducted with full-time municipal employees comprising HR managers and employees from a cross-section of occupational office levels within South African municipalities. Interviews were conducted in the boardroom facilities and private offices of the respective municipalities for a duration of $45 \mathrm{~min}$ per interview. 


\section{Entrée and establishing research roles}

The researcher's roles included planning the research project, serving as an instrument for data collection, transcribing and analysing the data as well as report writing. Access to the research setting was undertaken by obtaining permission from the municipal managers of the respective municipalities. Once permission was obtained and interview dates scheduled, participants were reassured of confidentiality and interviews were conducted in English. In addition, participants were issued with a consent form, which made it clear that participation in the study was voluntary. The data collected by the researcher were transcribed and analysed. The data were analysed through thematic analysis. Thematic analysis provides a structure of themes that serve as groups of codes that are repeated through similarities and connections to one another in terms of patterns (Buetow, 2010). Finally, the researcher remained objective throughout the study and therefore did not become biased or emotionally involved (Ritchie \& Lewis, 2003).

\section{Research participants and sampling methods}

The methods used for the present study were convenience, quota and purposive sampling techniques. In convenience sampling, participants are chosen based on availability, and easy accessibility and willingness to cooperate (Foxcroft \& Roodt, 2013). Although the present study adopted a convenience sampling method, participants still had to comply with certain criteria (Struwig \& Stead, 2001) - for example, full-time employment, a municipal manager at a municipality within the Eastern Cape, North West and Gauteng Provinces. According to Corbin and Strauss (2008), qualitative research allows the researcher to understand the points of view of participants in a way that the responses are unbiased by extant research. The researcher reported the data as provided by the research participants, with the aim to stay neutral throughout the study and still capture the unique viewpoints of the individual participants. The participants' unbiased viewpoints were important for the present research as they allowed for plausibility.

Quota sampling selects according to the characteristics of candidates, where the researcher decides how the quotas are assigned (Struwig \& Stead, 2001). The reason for choosing quota sampling in the present study was that participants were selected in proportion with the organisational structure, comprising three HR managers $(n=3)$ and 12 employees from a cross-section of occupational office levels $(n=12)$. This included one HR manager and four employees from each of the respective municipalities. In purposive sampling, participants are chosen for a specific purpose according to the researcher's own judgements (Leedy \& Ormrod, 2014). The inclusion criteria were further used during the sampling process. Inclusion criteria are predefined characteristics used in identifying subjects who will be included within a research study (Salkind, 2010). The reason for choosing purposive sampling and the inclusion criteria was primarily that the participants (municipal HR managers and employees) had most of the characteristics that best represented the purpose of the study (Gerrish \& Lacey, 2010; Grinnell \& Unrau, 2008).

\section{Data collection methods}

The interviews were semi-structured and one-on-one. According to Dicicco-Bloom and Crabtree (2006), semistructured interviews are often used in qualitative research and are organised generally around a set of predetermined open-ended questions, with additional questions emerging from the dialogue between interviewer and interviewee. The open-ended questions are posed in a systematic way and interviewees are encouraged to provide their own views (Struwig, Struwig, \& Stead, 2013). The present study made use of these types of interviews, which helped the researcher explore and describe the participants' experiences about past and present events with a view of reaching the goals of the study (De Vos, Strydom, Fouché, \& Delport, 2011).

The interview questions that follow were divided into two sets. The first set of questions focused on HR managers, and the second set on employees from a cross-section of occupational office levels within South African municipalities. The questions were few and open-ended, which allowed the researcher to probe, follow up and clear up any leads that occurred during the allocated interview period (Bryman, 2016). The questions posed during the interviews are represented in Figure 1.

Prior to posing these questions, a broad example of HR policies was given to the participants only when they indicated they did not understand the question. This helped ensure that the questions were answered to the best of their ability.

\section{Recording of data}

A recording device was used to collect, analyse and transcribe the data. The data on the tape recorder were transferred to a USB drive and secure cloud storage, and subsequently the inteviews were transcribed and imported into an excel sheet. To comply with the ethical requirements of confidentiality,

The following interview questions were focused on human resource managers
1. How are human resource policies (recruitment and selection, learning and
development and performance management) being communicated to
employees within your organisation?
2. What do you find challenging when implementing the human resource
policies within your organisation?
The following interview questions were focused on employees from a
cross-section of occupational office levels
1. How has human resources informed you about the human resource policies
being implemented within your organisation?
2. What is your experience of how the human resource policies are being
implemented within your organisation?
3. What challenges have you experienced in how the human resource policies
are implemented by management?

FIGURE 1: Interview questions. 
all the interview data (tape recorded and transcribed sheets) were placed in a secure location, in the office of the researcher's supervisor.

\section{Data analysis}

Thematic analysis is used to analyse qualitative descriptions. Through the thematic analysis, the researcher can identify, analyse and report patterns, ensuring the results are as accurate as possible (Braun \& Clarke, 2006). The researcher reflected on the relationships, categories, themes and concepts from the data, as part of a continuous process (Henning, Van Rensburg, \& Smith, 2004). The successive phases of thematic analysis are discussed in the following subsections.

\section{Phase 1: Get acquainted with the data}

The researcher familiarised herself with the collected data by reading through the interview questions and the written notes. Acquaintance involved 'repeated reading' of the data as well as searching for meaning and patterns within the data (Braun \& Clarke, 2006).

\section{Phase 2: Generating initial codes}

In this phase, the researcher produced initial codes from the data (Braun \& Clarke, 2006) by compiling general and overarching ideas that would lead to specific categories (codes). Codes were determined by the interview questions posed to the participants. For the present study, the researcher utilised Microsoft Excel to analyse, reduce and interpret the data.

\section{Phase 3: Searching for themes}

Once the data were coded and collated, the overarching themes were developed for each code. This was done by separating meaningful items into categories of central themes. This technique allows researchers to review themes and classify these into smaller sub-themes with the assistance of co-coders.

\section{Phase 4: Reviewing themes}

This phase began once a set of possible themes had been devised and thereafter refined (Braun \& Clarke, 2006). During this phase, it became evident that certain identified contents were not true themes; other themes had to be broken down into separate units, whilst others collapsed into each other (Braun \& Clarke, 2006). Furthermore, the researcher read through the themes again to confirm the correct coding and that the themes represented the entire dataset.

\section{Phase 5: Defining and naming themes}

In this phase, the themes captured from the analysis were defined and refined. It was important that, at the end of this phase, the researcher distinguished clearly between the relevant themes for the study (Braun \& Clarke, 2006). The researcher then allocated names to the themes, which reflected the true content of the data.

\section{Phase 6: Producing the report}

This phase began once the researcher had a set of fully worked-out themes and involved the final analysis and write-up of the report (Braun \& Clarke, 2006). Each of these descriptions was provided its own table, with relevant themes and characteristics. Finally, the researcher analysed the data to extract themes, used different approaches to examine the information and followed the guidelines for reflecting on these themes. In this regard, the data yielded an explicit structure of the meaning from the lived experiences of the participants regarding the usage and influence of HR policies.

\section{Strategies employed to ensure quality data and integrity}

The qualitative research approach adheres to four criteria for trustworthy data, namely credibility, transferability, dependability and conformability (Lincoln \& Guba, 1999).

Credibility (internal validity) is a procedure according to which participants of the study identify with the research findings (De Vos et al., 2011). A strategy of prolonged engagement was done by ensuring that both the researcher and the co-coder analysed and coded the data (Schurink, Fouche, \& De Vos, 2011).

Transferability (external validity) refers to whether individuals from different settings can relate to the particular research findings. The data of the present study could be transferred only to employees working within municipalities; therefore, transferability was achieved through rich descriptions of the data.

Dependability (reliability) refers to the consistency, structure and documentation of the research findings. Consistency is preserved by describing the data sufficiently, triangulation and audit trails (De Vos et al., 2011). The researcher documented the research process in a logical and well-structured manner to achieve dependability (Schurink et al., 2011).

Conformability (objectivity) is the level of objectivity the researcher reaches in the research findings (De Vos et al., 2011). It is therefore the researcher's responsibility to uncover reality in a manner that is objective, unbiased, unprejudiced and impartial. This ensured the researcher adhered to quality processes of evaluating the data. Furthermore, the researcher remained neutral throughout the study and did not manipulate the findings.

\section{Ethical considerations}

Approval from both the Industrial Psychology and Human Resource Management School's Scientific Research Committee and the EMS-REC (Economic and Management Sciences Research Ethics Committee) (NWU-01400-19-A4) was granted for this study. The considerations for the research study were based on ethical principles. Ethics can be defined 
as 'the morality of human conduct' that is followed in social research. Thus, ethics 'refers to moral deliberation, choice and accountability on the part of researchers throughout the research process' (Mauthner et al., 2005). According to Creswell (2013), when planning and designing a qualitative study, the researcher must consider the ethical issues that may surface during the process and plan how to address these matters. For the present study, the researcher was mindful of culture and individual differences amongst people. She also avoided discrimination against any person based on factors such as race, gender, age or status.

\section{Results}

The present study's research findings consisted of different categories, themes and responses, with direct quotations to support the results. The categories were divided according to the five questions that were posed during the interviews. The first two questions were directed specifically towards HR managers within municipalities. The last three questions focused on permanent employees from a cross-section of occupational office levels within South African municipalities.

\section{Category 1: How human resource policies are being communicated to employees within municipalities}

Category 1 provides the six broad themes indicating how the three mentioned HR policies are being communicated to employees within municipalities, from the HR managers' perspectives, as well as based on the verbatim original responses that were analysed.

The different meanings of the themes are discussed in the following subsections.

\section{Partial communication}

Participants reported that, most times, employees tend to be overlooked. There is a lack of communication with them about these HR policies; especially the performancemanagement policy is not communicated well within their municipalities:

'The one that is not well communicated and not a lot of people are asking about is the performance-management policy.' (Manager 1, 48, Male, manager: training and development; Manager 2, 55, Manager: Skills development; Manager 3, 53, Male, Acting manager: Human Resource Management)

\section{Workshops}

Participants pointed out that the mentioned three HR policies are communicated through organised workshops in which these policies are highlighted and applicable questions are answered:

'Ok, the ... we normally organise workshops; ja ... and that is where we take our employees through to whatever HR policies that we have.' (Manager 2, Manager: Skills development, 12 Dec 19; Manager 3, Acting manager: Human Resource Management, 21 Jan 20)

\section{Induction}

A participant explained that the communication of these HR policies takes place during the induction of newly appointed employees who receive a collection of relevant policies (bundle) for the particular municipality (Manager 3).

\section{Website}

One participant reported that the mentioned three HR policies are communicated through the municipality's website, where they also are available to the public (Manager 3).

\section{Management-level discussions and consultations}

According to a participant, the performance-management policy is discussed and consulted at the management level (Manager 3):

'We are having intense discussions and consultations at management level regarding the performance-management policy.' (Manager 3, Acting, Manager: Human Resource Management, 21 Jan 2020)

\section{Local labour forum}

A participant mentioned that HR policies are communicated through the local labour forum within the municipality (Manager 1).

\section{Category 2: Challenges in implementing human resource policies within municipalities}

Category 2 presents the 13 broad themes describing the challenges HR managers experience when implementing the mentioned three HR policies within the municipalities. The themes include the verbatim original responses that were analysed. The different meanings of the themes are discussed in the following subsections.

\section{Low employee morale}

One participant identified that low morale amongst employees poses a challenge to implementing these HR policies (Manager 1).

\section{Lack of participation}

A participant pointed out that employees are currently not participating in the implementation of the skills audits for the learning-and-development policy, which is a challenge (Manager 1).

\section{Lack of trust}

One participant acknowledged that employees do no trust management, particularly after the amalgamation of the municipality with another. The distrust poses a challenge to the implementation of these HR policies (Manager 1).

\section{Lack of communication}

Participants pointed out that their municipalities currently find it a challenge to organise the entire institution in order to communicate the HR policies: 
'Currently it's a challenge to organise the whole institution when we communicate the HR policies.' (Manager 1, 48, Male, manager: training and development; Manager 2, 55, Manager: Skills development)

\section{No clear guidance}

Participants explained that for the draft recruitment-andselection policy as well as the draft learning-and-development policy, managers follow their instincts and interpret issues differently. This lack of clear guidance is currently a challenge within their municipalities:

'Recruitment-and-selection area and learning and development, because of the absence of these policies because everyone wants to interpret issues the way they want to, ja, because there is no clear guidelines that are approved by the municipality.' (Manager 1, Manager: Training and Development, 6 Dec '19; Manager 2, Manager: Skills Development, 12 Dec '19)

\section{Employee dissatisfaction}

A participant mentioned that employees are unhappy and therefore the municipality is receiving numerous grievances that present challenges to implement the recruitment-andselection policy (Manager 2).

\section{Implementation regarding section 56 and 57 managers}

Participants pointed out that the performance-management policy, implemented only for directors, poses a weakness, and its implementation for other occupational levels within their municipalities is a challenge:

'Performance-management policy is the most challenging, like I said it's only ... focuses on employees who are ... the directors, let me say. Section 57 in terms of the Municipal Systems Act, those who report directly to the municipal manager.' (Manager 2, Manager: Skills Development, 12 Dec '19; Manager 3, Acting Manager: Human Resource Management, 21 Jan '20)

\section{Paying performance bonus}

One participant reported that financial constraints within the municipality make it difficult to pay senior managers their performance bonuses in accordance with the performancemanagement policy (Manager 3).

\section{Political interference}

Certain participants reported that politicians' interference makes it difficult to implement policies, especially the recruitment-and-selection policy:

'With the recruitment-and-selection policy, the difficulty in implementing that one is the old elephant in the room, political interference, because we always have to fight them off.' (Manager 1, Manager: Training and Development, 6 Dec '19; Manager 3, Acting Manager: Human Resource Management, 21 Jan '20)

\section{Training drop-out rate}

A participant mentioned that candidates who drop out from training interventions before completing the course pose a challenge to implementing the learning-and-development policy (Manager 2).

\section{Earmarked comrades}

According to a participant, political comrades who have been earmarked for vacant positions pose a challenge for the recruitment-and-selection policy (Manager 3).

\section{Downsizing of budget}

A participant mentioned the downsizing of the budget for training interventions, which would result in rearranging of the annual training plans, as a challenge when implementing the learning-and-development policy (Manager 3).

\section{Union resistance}

One participant reported that resistance from trade unions is the reason why the performance-management policy is not cascaded to occupational levels other than senior managers. This is a challenge when implementing the performancemanagement policy (Manager 3).

\section{Category 3: How has the human resources department informed employees about human resource policies that are implemented within municipalities?}

Category 3 presents the 11 broad themes explaining how employees have been informed about the mentioned three HR policies implemented within municipalities. This includes the original responses that were analysed. The applications of the themes are discussed in the following subsections.

\section{Training}

Participants mentioned that they normally are taken to training, where they are informed of the mentioned HR policies implemented within their municipalities:

'We were taken to training and we were told there, then we came back and worked here at the offices. I went once to this training in 2016 and we were told about these policies.' (Employee 1, Receptionist, 6 Dec '19; Employee 7, IT practitioner, 12 Dec '19)

\section{Not informed}

Participants reported that the HR department has not informed them about these policies:

'Actually no, from my side, HR has not informed me of these HR policies since I have been employed, no.' (Employee 2, Community services Clerk, 6 Dec '19; Employee 4, Labour Relations practitioner, 6 Dec '19; Employee 9, Finance Administrator, 21 Jan '20; Employee 10, Finance Senior Clerk, 21 Jan '20; Employee 12, LED Senior Clerk, 21 Jan ‘20)

\section{Induction}

The participant explained that the HR department provided information on the mentioned policies during the induction process, after they were appointed to the municipality (Employee 1).

\section{Union participation}

A participant confirmed that information on the HR policies was communicated through the trade unions (Employee 6). 


\section{Meetings}

Participants reported that they were informed about the implementation of HR policies through meetings held at the library and the municipalities (Employees 5 and 7).

\section{Emails}

Participants pointed out that, normally, the implementation of HR policies is communicated to them through individual and group emails (Employees 5 and 6).

\section{Road show}

A participant mentioned that the implementation of the learning-and-development policy was communicated during a road show (Employee 9).

\section{Newsletter or memo}

A participant reported that the training department sends memos or newsletters through email whenever training is needed in their municipality (Employee 10).

\section{Uncertainty}

Certain participants mentioned they are uncertain of the ways the HR department informs them about the implementation of the performance-management policy (Employees 9 and 10):

'You know the performance policy, I cannot dwell too much on that because it's for senior management, which is section 56 , so, I don't have to say much about performance policy, I'm not sure.' (Employee 9, Finance Administrator, 21 Jan '20; Employee 10, Finance Senior Clerk, 21 Jan '20)

\section{Workshop}

Participants indicated that they are informed of the recruitment-and-selection policy as well as training-anddevelopment policy by attending workshops, which focus specifically on communicating HR policies (Employees 8 and 11).

\section{Website}

A participant reported that information on HR policies is posted on their municipality's website and made available to the public (Employee 11).

\section{Category 4: Experience of how human resource policies are being implemented within municipalities}

Category 4 provides 11 broad themes indicating employees' experiences of the way the three mentioned HR policies are being implemented within municipalities. These themes are confirmed by the verbatim original responses that were analysed. The different meanings of the themes are discussed in the following subsections.

\section{No experience}

Participants reported that they have had no experience of the performance-management policy being implemented:
'On performance policies, no ... at the moment we don't have any experience of that.' (Employee 2, Community services Clerk, 6 Dec '19; Employee 4, Labour Relations practitioner, 6 Dec '19; Employee 9, Finance Administrator, 21 Jan '20; Employee 12, Local Economic Development Senior Clerk, 21 Jan ‘20)

\section{Positive experience}

Certain participants mentioned that they had a pleasant and positive experience regarding the implementation of the recruitment-and-selection policy as well as the learning-anddevelopment policy:

'My experience? Well, my recruitment was a good experience, I thought it was fair. So, that's how I feel about the recruitmentand-selection policies.' (Employee 1, Receptionist, 6 Dec '19; Employee 11, HR Practitioner, 21 Jan '20)

\section{Compliance checklist}

One participant pointed out that the mentioned HR policies were used as a check-list for those implementing the policies on which to comply (Employee 12).

\section{Corruption}

One participant mentioned that they experience corruption during appointments, when implementing the recruitmentand-selection policy (Employee 9).

\section{No training opportunities}

Participants reported that they are not afforded the chance to attend training interventions at the expense of the municipalities:

'I haven't been included by that. I have not gone to a training.' (Employee 2, Community services Clerk, 6 Dec '19; Employee 4, Labour Relations practitioner, 6 Dec '19; Employee 7, IT practitioner, 12 Dec '19; Employee 8, Legal services practitioner, 12 Dec '19)

\section{Attended training}

Certain participants pointed out the learning-anddevelopment policy, which provides training programmes and learnerships:

'For training and development, I did experience it because I was once in training whereby I developed so many skills, neh.' (Employee 3, Directorate Secretary, 6 Dec '19; Employee 4, Labour Relations practitioner, 6 Dec'19; Employee 5, clerk, 12 Dec '19)

\section{Lack of supervision}

Regarding the performance-management policy, participants explained that they experienced the absence of managers and supervisors, who should be monitoring their performance within the municipalities:

'We don't see the managers because they are in the other town most of the time, so there's never staff meetings ... there's nothing. You just come to work and you do whatever you find to do.' (Employee 2, Community services Clerk, 6 Dec '19; Employee 3, Directorate Secretary, 6 Dec '19; Employee 12, Local Economic Development Senior Clerk, 21) 


\section{Implementation bias}

One participant mentioned that during the implementation of the recruitment-and-selection policy, they had a disagreement with an HR official. As a result, employees were excluded unfairly from the process to fill a vacancy (Employee 9).

\section{Selective implementation}

Participants reported selective and inconsistent implementation of the recruitment-and-selection policy, particularly during placement:

'When they do this placement you sometimes find that there are inconsistencies.' (Employee 2, Community services Clerk, 6 Dec '19; Employee 6, Procurement clerk, 12 Dec '19; Employee 12, LED Senior Clerk, 21 Jan '20)

\section{Unpleasant experience}

One participant found the implementation of the three mentioned HR policies to be an unpleasant experience (Employee 6).

\section{No job description}

A participant singled out the implementation of the recruitment-and-selection policy, indicating employees do not know their job description or who they currently report to within the municipality (Employee 2).

\section{Category 5: Challenges experienced in the way management implements human resource policies}

Category 5 presents the broad 11 themes that indicate the challenges employees experience in the way the three mentioned HR policies are implemented within municipalities. This includes the verbatim original responses that were analysed. The different meanings of the themes are discussed in the following subsections.

\section{No challenges}

Certain participants reported that they did not experience any challenges in the way these HR policies are implemented within municipalities (Employees 1 and 11):

'I did not have any challenges in recruitment and selection implementation. With training and development, I was taught to do my work and also to answer the phone, there were not challenges with that policy. It helped me.' (Employee 1, Receptionist, 6 Dec '19; Employee 11, HR practitioner, 21 Jan '20

\section{Lacking contract of employment}

A participant mentioned that working for 3 years in the municipality without an employment contract was a challenge regarding the recruitment-and-selection policy (Employee 2).

\section{Application inconsistencies}

A participant indicated further challenges that employees experience, namely inconsistencies in applying the mentioned HR policies (Employee 6).

\section{Incomplete training}

One participant reported that they were unable to complete a training programme because the municipality discontinued the course. This challenge concerned the implementation of the learning-and-development policy (Employee 3).

\section{No performance evaluation}

Participants found that the lack of performance monitoring and evaluation is a challenge regarding the performancemanagement policy:

'There is a challenge again with performance management because I don't know what I am doing, is it right or wrong.' (Employee 7, IT practitioner, 12 Dec '19; Employee 9, Finance Administrator, 21 Jan '20; Employee 10, Finance Senior Clerk, 21 Jan '20; Employee 12, LED Senior Clerk, 21 Jan '20)

\section{No training}

A challenge the participants pointed out regarding the learning-and-development policy is that they have not been taken to any training programmes:

'My challenge with the training policy implementation is that I complete a skills questionnaire every year and still I don't see myself taken to any training.' (Employee 2, Community services Clerk, 6 Dec '19; Employee 9, Finance Administrator, 21 Jan'20)

\section{Irrelevant training}

One participant identified a challenge with the implementation of the learning-and-development policy. Whenever they are taken to a training initiative, employees find that the training is irrelevant to the work they do (Employee 12).

\section{No upward mobility}

A participant identified a challenge in the implementation of the mentioned HR policies, that is, being employed in the same job position for years without upward movement within the municipality (Employee 12).

\section{Lacking human resource policy knowledge}

For another participant, the challenge is a lack of knowledge about these mentioned HR policies (Employee 10).

\section{Management investment}

A participant reported a challenge regarding the learning-anddevelopment policy, where training is provided only to politicians and managers within the municipality (Employee 2).

\section{Micro-management}

One participant mentioned a challenge in implementing the performance-management policy, namely being micromanaged by the supervisor (Employee 12).

\section{Discussion}

\section{Outline of the findings}

The results indicated that most participants reported partial communication with employees about the mentioned HR 
policies. The responses indicate that specifically the performance-management policy is not communicated well within the municipalities as it is discussed and consulted at the management level. According to literature, organisational communication often has two goals: firstly, to inform employees about policies and their tasks; and secondly, to create community within the organisation (Elving, 2005). Communication is vital for the effective implementation of any potential change to the organisation, brought about by HR policies (Bos-Nehles et al., 2013; Elving, 2005). One participant reported that communication of the three mentioned HR policies takes place during the induction period of newly appointed employees. During that period, employees receive bundles of the municipality's relevant policies. Literature encourages this practice, as the most successful organisations of the future will be distinguished for their ability to encourage inclusion of all employees and make decisions to gain new knowledge on the organisation's policies (Brynard, 2009; Dragomiroiu, Hurloiu, \& Mihai, 2014).

The findings of this study indicated that the most reported challenges by participants are: (1) no clear guidance, (2) political interference and (3) implementation regarding section 56 and 57 managers. Regarding the lack of clear guidance, certain participants reported that recruitment and selection as well as L\&D are still draft policies; managers follow their instincts and interpret issues differently. According to literature, the absence of coordination and clear definition of policy objectives and responsibility amongst policy implementers may lead to challenges in implementation (Ahmed \& Dantata, 2016). Regarding political input, participants mentioned interference from politicians in terms of appointments, which leads to challenges when implementing the recruitment-and-selection policy. Previous literature confirms this tendency, as politicians do influence HR policy outputs and outcomes at local organisational level (May \& Winter, 2007). Furthermore, political interferences have no doubt a far-reaching influence on the effective implementation of HR policies (Ahmed \& Dantata, 2016). Certain participants reported that the performance-management policy is only implemented with regards to directors, which poses a challenge in its implementation for other occupational levels within the municipalities. However, literature states that numerous managers have recognised that differences in the application of HR policies may bring different outcomes, which may be negative for the organisation (Bos-Nehles et al., 2013).

The present research findings indicate that most participants reported they have not been informed by the HR department about the implementation of these HR policies: 'Actually no, from my side, HR has not informed me of these HR policies since I have been employed, no'. According to Postmes, Tanis and De Wit (2001), employees become more committed when they obtain adequate information. Furthermore, the communication of information influences feelings of community and belonging within the organisation (Elving, 2005). Therefore, according to literature, it is important that management knows how to communicate policies and procedures to staff effectively (Clear HR Consulting, 2019). In terms of their experiences, the most common finding from participants was that they have no experience of the performance-management policy being implemented. On the other hand, the responses show that participants had a pleasant and positive experience regarding the implementation of the recruitment-and-selection policy as well as the learning-and-development policy. Literature encourages this trend, as training and staffing policies and practices help foster an organisation's human capital (BeltranMartin \& Bou-Llusar, 2018).

Participants also reported challenges where the mentioned three HR policies are applied inconsistently. It is therefore necessary to avoid individual judgement and potential bias within the HR policies and its interpretation by clearly defining the way HR activities are performed in practice (Bos-Nehles et al., 2013). A specific challenge was highlighted regarding the implementation of the learningand-development policy. Whenever employees are taken to a training initiative, they find that the content is irrelevant to their work. This finding is in line with literature, as there is evidence that few organisations provide formal and systematic training (Brewster, 2000; Harris, Doughty, \& Kirk, 2002). Bos-Nehles et al. (2013) found in previous research that numerous managers have recognised that differences in applying HR policies may result in different outcomes, a factor that may be negative for the organisation.

In conclusion, as reported by all HR managers, it is clear that all three HR policies (recruitment and selection, L\&D and performance management) are currently communicated within municipalities. However, in certain instances, the challenges experienced by employees are that the policies are partially communicated. In other instances, employees experienced a lack in the communication of the performance management policy. Furthermore, employees reported both positive and negative experiences of these three HR policies.

\section{Practical implications}

As a consequence of their participation in this study, local government realises the importance of annually training the HR managers and evaluating their performance, as custodians and implementers of HR policies, on their effective communication and implementation of the three investigated policies. This communication and implementation of the policies should benefit employees across occupational levels within the municipality. Municipalities, in collaboration with their HR managers, should communicate all learning-and-development interventions to the relevant occupational levels, on a quarterly basis, through the municipalities' intranet, emails and the noticeboard. The aim must be to inform as many employees as possible regularly and make them aware of the available training opportunities. 


\section{Limitations}

The sample was restricted to HR managers and office-based employees within South African municipalities. The study did not include the municipalities' water and sanitation plant-based workers and roads workers. Therefore, the study may be limited in the generalisation of its results to all municipal employees. From a methodological point of view, a small sample was used. This sample size cannot be extended to a wider population with the same degree of certainty as a larger sample. The present study was conducted in the Eastern Cape, North West and Gauteng provinces; therefore, the results cannot be generalised to other parts of the country. However, the study was applied in only three of the nine provinces in South Africa.

\section{Recommendations}

For future research, the study can be extended to include municipal employees holding positions within the water and sanitation plant as well as the roads department. A larger sampling population can be used, which incorporates participants from all nine South African provinces. Following up the present study with quantitative research would allow for the generalisation of the research (Bryman, 2016). Such an expanded study will enable accurate generalisations on the use and influence of HR policies within South African municipalities.

Municipalities, in collaboration with the directorate and political councillors, should prioritise the renewal and timeous adoption of the three mentioned HR polices. Such measures will help avoid ambiguity and uncertainties in the interpretation and implementation of these policies. Management should implement motions to cascade the performance-management policy. Municipalities should plan biannual HR policy roadshows catering to all municipal employees. During such contact sessions, the three mentioned HR policies can be communicated effectively to employees, and questions posed and answered. The HR department should lay out stricter guidelines around the recruitment-andselection policies. Such guidelines should mitigate interferences in the staffing and appointing processes from external bodies outside the assigned recruitment-and-selection panel.

It is recommended that HR managers attend a variety of courses in HR policy implementation. This will help keep them abreast of changes in such implementation. Human resource managers should establish a database that captures the relevant skills-audit information from employees. Such a database will ensure employees are afforded training opportunities relevant to the work that the municipalities have appointed them to do.

In conclusion, the performance of municipalities in South Africa is under the spotlight, and consequently local government needs to understand that employee performance is critical to the overall success of the organisation. The HR department and its policies hold the administrative expertise to effect real change within the workplace and should, on that account, be extensively used and implemented.

\section{Acknowledgements Competing interests}

The authors declare that they have no financial or personal relationships that may have inappropriately influenced them in writing this article.

\section{Authors' contributions}

L.M. collected, captured and analysed the data and wrote the manuscript. N.D.P.M. supervised the study, and assisted with the data analysis and provided feedback on the manuscript.

\section{Funding information}

This research received no specific grant from any funding agency in the public, commercial or not-for-profit sectors.

\section{Data availability}

Raw data sets are available upon request from the corresponding author.

\section{Disclaimer}

L.M. and N.D.P.M. hereby declare that 'Exploring the use and influence of human resource policies within South African municipalities' is their own work. The views and opinions expressed in this work are those of the authors and do not necessarily reflect the official policy or position of any affiliated agency of the authors.

\section{References}

Ahmed, I.K., \& Danatata, B.S. (2016). Problems and challenges of policy implementation for nation development. Research on Humanities \& Social Sciences, 6(15), 60-65.

Appelbaum, E., Bailey, T., Berg, P., \& Kallegerg, A.L. (2000). Manufacturing advantage: Why high-performance work systems pay off. New York, NY: Cornell University Press.

Beltran-Martin, I., \& Bou-Llusar, J.C. (2018). Examining the intermediate role of employee abilities, motivation and opportunities to participate in the relationship between HR bundles and employee performance. Business Research Quarterly, 21(2), 99-110. https://doi.org/10.1016/j.brq.2018.02.001

Bhuyan, A., Jorgensen, A., \& Sharma, S. (2010). Taking the pulse of policy: The policy implementation assessment tool. Washington, DC: Futures Group, Health Policy Initiative, Task Order 1.

Bos-Nehles, A.C., Van Riemsdijk, M.J., \& Looise, J.K. (2013). Employee perceptions of line management performance: Applying the AMO theory to explain the effectiveness of line managers' HRM implementation. Human Resource Management, 52(6), 861-877. https://doi.org/10.1002/hrm.21578

Bradshaw, C., Atkinson, S., \& Doody, O. (2017). Employing a qualitative description approach in health care research. Global Qualitative Nursing Research, 4, 1-8. https://doi.org/10.1177/2333393617742282

Braun, V., \& Clarke, V. (2006). Using thematic analysis in psychology. Qualitative Research in Psychology, 3(2), 1-27.

Brewster, C., \& Larsen, H.H. (2000). Responsibility in human resources management: The role of the line. In C. Brewster, \& H.H. Larsen (Eds.), Human resource management in Northern Europe (pp. 195-218). Oxford: Blackwell.

Bryman, A. (2016). Social research methods (5th edn.). Oxford: Oxford University Press.

Brynard, P.A. (2009). Mapping the factors that influence policy implementation. Journal of Public Administration, 44(3), 557-577. 
Buetow, S. (2010). Thematic analysis and its reconceptualization as 'saliency analysis'. Journal of Health Services Research \& Policy, 15, 123-125. https://doi. org/10.1258/jhsrp. 2009.009081

Burns, N., \& Grove, S.K. (2009). The practice of nursing research: Appraisal, synthesis and generation of evidence. Maryland Heights, MO: Saunders Elsevier.

Cammarata, L. (2012). Phenomenology and hermeneutics. In C.A. Chapelle. (Ed.), The Encyclopaedia of applied linguistics. Hoboken, NJ: Wiley-Blackwell. https://doi. org/10.1002/9781405198431.wbeal0905

Cheema, S., \& Javed, F. (2017). The effects of corporate social responsibility toward green human resource management: The mediating role of sustainable environment. Cogent Business \& Management, 4(1), 1-10. https://doi.org/10.10 80/23311975.2017.1310012

Clear HR Consulting (2019). Re: Performance management cycle - How to effectively manage performance [Blog comment]. Retrieved January 10, 2019, from https:// clearhrconsulting.com/blog/

CIPD. (2019a). Strategic human resource management. Retrieved from https://www. cipd.co.uk/knowledge/strategy/hr/strategic-hrm-factsheet

CIPD. (2019b). What are HR policies? Retrieved from https://www.cipd.co.uk/ knowledge/fundamentals/people/hr/policies-factsheet\#7702

Cloete, H.C.A., Eigelaar-Meets, I., Fortuin, A.J., \& Sewell, W.J. (2016). The challenges faced by the municipal skills development facilitator in the planning and faced by the municipal skills development facilitator in the planning and
implementation of skills development interventions. Retrieved from https://www. implementation of skills development interventions. Retrieved from https://WWW. google.com/url?sa=t\&rct=j\&q=\&esrc=s\&source=web\&cd=1\&ved=2ahUKEwjRmf
v3|4zhAhXUQxUIHdqABUwOFjAAegQIChAC\&url=http $\% 3 A \% 2 F \% 2$ Fcdn.lgseta. v $3 \mid 4$ zhAhXUQxUIHdqABUwOFjAAegQIChAC\&url=http $\% 3 \mathrm{~A} \% 2 \mathrm{~F} \% 2 \mathrm{Fcdn}$.Igseta.
co.za $\% 2$ Fresources $\% 2$ Fperformance monitoring_and_reporting_documents $\% 2$ co.za\%2Fresources\%2Fperformance_monitoring_and_reporting_documents $\% 2$
FSDF\%2520Research\%2520Project.pdf\&usg=AOVVawOhtiraEzYpOer1N1fxNcGy

Cooperative Governance Traditional Affairs. (2018). 2018 annual report. Retrieved from http://www.cogta.gov.za/?p=352

Corbin, J., \& Strauss, A. (2008). Basics of qualitative research: Techniques and procedures for developing grounded theory. London: Sage.

Creswell, J.W. (2013). Qualitative inquiry and research design: Choosing among five approaches (3rd ed.). London: SAGE.

Cummings, L.L., \& Schwab, D.P. (1973). Performance in organizations. Glenview, IL: Scott, Foresman and Company.

Demo, G., Neiva, E.R., Nunes, I., \& Rozzett, K. (2012). Human resources management policies and practices scale (HRMPPS): Exploratory and confirmatory factor
analysis. Brazilian Administration Review, $9(4), 396-420$. https://doi.org/10.1590/ analysis. Brazilian Administratio

Denzin, N.K., \& Lincoln, Y.S. (1994). Handbook of qualitative research. Riverside County, CA: Sage.

De Vos, A.S., Strydom, H., Fouché, C.B., \& Delport, C.S.L. (2011). Research at grassroots: For the social sciences and human service professions (4th edn.). Pretoria: Van Schaik.

Dicicco-Bloom, B., \& Crabtree, B. (2006). The qualitative research interview. Wiley Online Library. https://doi.org/10.1111/j.1365-2929.2006.02418.x

Dragomiroiu, R., Hurloiu, I., \& Mihai, G. (2014). Induction staff training. Procedia Economics and Finance, 16, 368-373. https://doi.org/10.1016/S2212 5671(14)00815-6

Edmonds, W.A., \& Kennedy, T.D. (2013). An applied reference guide to research design: Quantitative, qualitative, and mixed methods. Riverside County, CA: Sage.

Elving, W.J.L. (2005). The role of communication in organisational change. Corporate Communications: An International Journal, 10(2), 129-138. https://doi. org/10.1108/13563280510596943

Firestone, W.A. (1989). Using reform: Conceptualizing district initiative. Educationa Evaluation \& Policy Analysis, 11(2), 151-164. https://doi.org/10.3102/ 01623737011002151

Foxcroft, C., \& Roodt, G. (2013). Introduction to psychological assessment in the South African context (4th edn.). Cape Town: Oxford University Press.

Gerrish, K., \& Lacey, A. (2010). The research process in nursing (6th edn.). Chichester: Wiley-Blackwell.

Grinnel, R.M., \& Unrau, Y.A. (2008). Social work research and evaluation: Foundations of evidence-based practice. New York, NY: Oxford University Press.

Guba, E. \& Linclon, Y. (1999). Establishing trustworthiness. In A. Bryman \& R.G Burgess (Eds.), Qualitative Research, vol. 3 (pp. 397-444). Thousand Oaks California: Sage Publications.

Guest, D.E. (1997). Human resource management and performance: A review and research and research agenda. International Journal of Human Resource Management, 8(3), 263-276. https://doi.org/10.1080/095851997341630

Hamlin, B., \& Stewart, J. (2011). What is HRD? A definitional review and synthesis of the HRD domain. Journal of European Industrial Training, 35(3), 199-216.

Harris, L. (2005). UK public sector reform and the 'performance agenda' in UK local government. Personnel Review, 34(6), 681-696. https://doi.org/10.1108/ 00483480510623466

Harris, L., Doughty, D., \& Kirk, S. (2002). The devolution of HR responsibilities Perspectives from the UK's public sector. Journal of European Industrial Training, 26(5), 218-229. https://doi.org/10.1108/03090590210424894

Hall, D., Pilbeam, S., \& Corbridge, M. (2013). Contemporary themes in strategic people management. A case-based approach. Basingstoke: Palgrave Macmillan.

Henning, E., Van Rensburg, W., \& Smith, B. (2004). Finding your way in qualitative research. Pretoria: Van Schaik Publishers.

Hill, A. (1987). The strategic approach to human resources management. IPM Journal, 5(9), 6-9.
Howlett, M. (2009). Government communication as a policy tool: A framework for analysis. The Canadian Political Science Review, 3(2), 23-37.

Hugh, J. (2007). Paper presented at the 40th Hawaiian International Conference on Systems Sciences, University of Texas, Pan-American, TX.

Hunter, C. (2012). Managing people in South Africa: Human resource management as competitive advantage. Durban: Sherwood Books.

Katou, A.A., \& Budhwar, P.S. (2010). Causal relationship between HRM policies and organisational performance: Evidence for the Greek manufacturing sector European Management Journal, 28(1), 25-39. https://doi.org/10.1016/j. emj.2009.06.001

Khambule, I. (2018). The role of local economic development agencies in South Africa's development state ambitions. Local Economy, 33(3), 287-306. https://doi. org/10.1177/0269094218766459

Kleynhans, R., Markham, L., Meyer, W., Van Aswegen, N., \& Pilbeam, E. (2009). Human resource management: Fresh perspectives. Cape Town: Pearson Prentice Hall.

Koma, S.B. (2010). The state of local government in South Africa. Journal of Public Administration, 45(1), 111-120.

Leedy, P.D., \& Ormrod, J.E. (2014). Practical research: Planning and design (10th edn.). Boston, MA: Pearson Education.

Legge, K. (1995). Human resource management: Rhetorics and realities. Houndmills: Macmillan Press.

Liamputtong, P. (2013). Research methods in health. South Melbourne: Oxford University Press.

Malagon-Maldonaldo, G. (2014). Qualitative research in health design. Health Environments Research \& Design Journal, 7(4), 120-134. https://doi. org/10.1177/193758671400700411

Mashamaite, K. (2014). Public service delivery protests in a democratic South Africa: A dilemma for local municipalities. Mediterranean Journal of Social Sciences, 5(25), 231-237. https://doi.org/10.5901/mjss.2014.v5n25p231

Mashamaite, K., \& Lethoko, M. (2018). Role of the South African local government in local economic development. International Journal of eBusiness and e Government Studies, 10(1), 114-128.

May, P.J., \& Winter, S.C. (2007). Politicians, managers, and street-level bureaucrats: Influences on policy implementation. Journal of Public Administration Research, 19, 453-476. https://doi.org/10.1093/jopart/mum030

Mauthner, M. L., Mauthner, M., Birch, M., Jessop, J., \& Miller, T. (2005). Ethics in qualitative research. London: SAGE.

Merriam, S.B. (2009). Qualitative research: A guide to design and implementation. San Francisco, CA: John Wiley \& Sons.

Merriam, S.B., \& Tisdell, E.J. (2016). Qualitative research: A guide to design and implementation. San Francisco, CA: Wiley.

Meyer, M. (2016). Managing human resource development: A strategic learning approach (5th edn.). Durban: Lexis Nexis.

Mthethwa, R.M. (2012). Critical dimensions for policy implementation. African Journal of Public Affairs, 5(2), 37-47. Retrieved from https://repository.up.ac.za/ bitstream/handle/2263/20618/Mthethwa_Critical\%282012\%29. pdf?sequence $=1$ \&isAllowed $=y$

National Capacity-building Framework (2008). The Department of Cooperative Governance in the Ministry of CoGTA. National Capacity Building Framework (NCBF): 2008 to 2011. Pretoria: CoGTA. Retrieved from https://www.yumpu.com/ en/document/view/28874427/national-capacity-building-frameworkparliamentary-monitoring-

Nel, P., Werner, A., Du Plessis, A., Ngalo, O., Poisat, P., \& Sono, T. (2011). Human resource management (8th edn.). Cape Town: Oxford University Press Southern Africa.

Paauwe, J. (2009) HRM and performance: Achievements, methodological issues and prospects. Journal of Management, 46(1), 129-142.

Pham, N.T., Tuckova, Z., \& Jabbour, C.J.C. (2018). Greening the hospitality industry: How do green human resource management practices influence organizational citizenship behaviour in hotels? A mixed- methods study. Journal of Tourism Management, 72, 386-399. https://doi.org/10.1016/j.tourman.2018.12.008

Postmes, T., Tanis, M., \& De Wit, B. (2001). Communication and commitment in organisations: A social identity approach. Group Process \& Intergroup Relations, 4(3), 207-226

Purcell, J., Kinnie, N., Hutchinson, S., Rayton, B., \& Swart, J. (2003). Unlocking the black box: Understanding the HR performance link. London: Chartered Institute of Personnel and Development.

Rayner, J., \& Morgan, D. (2018) .An empirical study of 'green' workplace behaviours: Ability, motivation and opportunity. Asia Pacific Journal of Human Resources, 56(1), 56-78. https://doi.org/10.1111/1744-7941.12151

Rees, G., \& Smith, P.E. (2017). Strategic human resource management. Los Angeles, CA: Sage.

Ritchie, J., \& Lewis, J. (2003). Qualitative research practice: A guide for social science researchers and students. London: Sage.

Roux, N.L. (2005). Unrest at the local sphere of government in South Africa: Unrealistic expectations or the inability to implement policies? Strategic Review of South Africa, 55-84. Retrieved from http://goliath.ecnext.com

Salkind, N.J. (2010). Encyclopedia of research design (Vols. 1-0). Thousand Oaks, CA: Sage. https://doi.org/10.4135/9781412961288 
Schurink, W., Fouché, C.B., \& De Vos, A.S. (2011). Qualitative data analysis and interpretation. In A.S. De Vos, H. Strydom, C.B. Fouché, \& C.S.L. Delport (Eds.) Research at grass root: For the social sciences and human service professions Research at grass root: For the social sciences
(4th edn., pp. 397-423). Pretoria: Van Schaik.

Schwella, E., Botha, C., Brand, D., Engelbrecht, M., \& Eijbergen, R. (2015). South African governance. Cape Town: Oxford University Press.

Siddle, A., \& Koelble, T. (2012). The failure of decentralization in South African local government. Cape Town: UCT Press.

Silverman, H.J. (1994). Textualities: Between hermeneutics and deconstruction. New York, NY: Routledge.

Smith, T.B. (1973). The policy implementation process. Policy Sciences, 4(2), 197-209. Retrieved from https://www.jstor.org/stable/4531525

South Africa. (1996). Constitution of the Republic of South Africa Act 108 of 1996. Pretoria: Government Printer.

South Africa. (1998). Local Government: Municipal Demarcation Act 27 of 1998. Pretoria: Government Printer.

South Africa. (2000a). Municipal Systems Act, no. 32 of 2000. Pretoria: Government Printer.

South Africa. (2000b). White paper on human resource management in the public service. Retrieved from http://www.polity.org.za/govdocs/white_papers/ servicedec.html

Spillane, J.P., Reiser, B.J., \& Reimer, T. (2002). Policy implementation and cognition Reframing and refocusing implementation research. Review of Education Research, 72(3), 387-431. https://doi.org/10.3102/00346543072003387
Sterling, A., \& Boxall, P. (2013). Lean production, employee learning and workplace outcomes: A case analysis through the ability-motivation-opportunity framework. Outcomes: A case analysis through the ability-motivation-opportunity framework.
Human Resource Management Journal, 23(3), 227-240. https://doi. org/10.1111/1748-8583.12010

Struwig, F.W., \& Stead, G.B. (2001). Planning, designing and reporting research. Cape Town: Pearson Education South Africa.

Struwig, M., Struwig, F., \& Stead, G. (2013). Data collection methods. In M. Struwig F. Struwig, \& G. Stead (Eds.), Planning, reporting and designing research (pp. 82-108). Cape Town: Pearson.

Swanepoel, B., Erusmus, B., Van Wyk, M., \& Schenk, H. (2003). South African human resource management theory and practice (3rd edn.). Cape Town: Juta \& Co Ltd.

Thornhill, C., \& Cloete, J.J.N. (2014). South African municipal government and administration. Pretoria: Van Schaik.

Tinti, J.A., Venelli-Costa, L., Vieira, A.M., \& Cappellozza, A. (2017). The impact of human resources policies and practices on organisational citizenship behaviours. Brazilian Business Review, 14(6), 636-653. https://doi.org/10.15728/bbr.2017.14.6.6

Umashev, C., \& Willett, R. (2008). Challenges to implementing strategic performance measurement systems in multi-objective organizations: The case of a large local government authority. A Journal of Accounting, Finance \& Business Studies, 44(4), 377-398. https://doi.org/10.1111/j.1467-6281.2008.00268.x

Van Manen, M. (1990). Researching lived experience: Human science for an action sensitive pedagogy. Albany, NY: State University of New York Press.

White, L. (2000). Changing the whole system in the public sector. Journal of Organizational Change, 13(2), 162-177. https://doi.org/10.1108/095348100 10321481 